\title{
SELVHJÆELPSORGANISERING I \\ ARBEJDERKLASSEN ELLER KONTROL MED \\ ARBEJDERKLASSENS REPRODUKTION \\ GENNEM STATSLIG SOCIALPOLITIK?
}

\section{Finn Hansson}

Kontrol har i den marxistiske diskussion oftest været forbundet med regulering af den materielle produktion, med værdilovens ophævelse. Men også arbejderklassens eksistens udenfor produktionsprocessen er underlagt kontrol og det har været erfaret gennem utallige konfrontationer med stat og kapital. Når kontrol og repression har antaget mindre synlige former i den nuværende (forhenværende?) velfærdsstat er det ikke ensbetydende med at kontrolproblemerne ikke længere er tilstede. Tværtimod, udover at kontrollen har ændret former har den også tiltaget i omfang i den forstand at flere og flere områder $i$ hverdagslivet direkte gennem kapitalen eller indirekte gennem staten er blevet underlagt den kapitalistiske kontrol og repression.

Følgende er nogle foreløbige overvejelser omkring et ofte forbigået problemområde i de nyere marxistiske socialpolitikanalyser, nemlig den statslige socialpolitisk direkte repressive og kontrollerende funktion overfor arbejderklassen. Baggrunden for disse overvejelser er en artikel af Marianne Rodenstein (MR) der i en historisk sammenhæng forsøger at undersøge »hvordan og med hvilke konsekvenser denne selvhjælpsorganisering bliver trængt bort af den statslig regulerede organisering af den individuelle sikring $i$ form af lovreguleret sygeforsikring. $\ll^{1}$
Det vil ikke være en overdrivelse at sige, at MR forstår den statslige socialpolitik primært ud fra et magtog politiksynspunkt. Dvs. MR fremstiller politikudviklingen som primært et resultat af den politiske magtkamp - og især af arbejderklassens ageren i politiske sammenhænge, dvs. den politiske organisering omkring socialdemokratiet.

Et sådant synspunkt på socialpolitikudviklingen fremhæver naturligvis spørgsmålet om den politiske formidlingsproces og om den sociale kontrol, der er indeholdt i den statslige socialpolitik. Men bagsiden er, at MR hele vejen igennem artiklen mister forståelsen for de konkrete materielle akkumulationsbestemte reproduktionsbetingelsers betydning for både reproduktionskampen i arbejderklassen $o g$ den statslige politikudformning.

Sigtet med MR's historiske analyse er at kunne bidrage til den aktuelle diskussion om selvhjælpsorganisering, decentralisering og 'modmagt' og i denne sammenhæng søge at besvare spørgsmålet om hvorledes det var muligt at den oprindelige selvhjælpsorganisering næsten gnidningsløst og uden større konflikter blev eller lod sig blive statsliggjort?

I en mere teoretisk forstand er problemet at MR ikke analyserer formsammenhængene mellem kapitalakkumulation og reproduktion af arbejdskraft og af denne 
grund ikke kan se, at den udvikling, som hun analyserer, er en specifik form for kapitalistisk samfundsmæssigg ørelse af arbejdskraftreproduktionen - betinget af modsætningerne mellem udviklingen i kapitalens akkumulationsbetingelser og reproduktionskrav og -betingelser til og for arbejdskraften.

At denne form for samfundsmæssiggørelse af dele af arbejdskraftens reproduktion sker i statslig regi er ikke overraskende. Tværtimod kan det inden for det borgerlige samfunds rammer kun ske i en statslig form - idet en direkte og umiddelbar kapitalsubsumering af dele af arbejdskraftreproduktionen på afgørende vis ville antaste bestemmelsen af denne reproduktion som individuel.

Men netop pga. sit politik- og magtcentrerede udgangspunkt lykkes det ikke for R. at lokalisere de ændrede materielle (akkumulationsbestemte) samfundsmæssige betingelser for arbejdskraftreproduktionen. Hendes overvejelser om selvhjælpsorganisering vs. statslig kontrol via socialpolitik, som et centralt problem for spørgsmålet om dannelse af en revolutionær klassebevidsthed, mister således helt en materiel basis. Spørgsmålet om materielle forudsætninger for ændrede reproduktionsbetingelser og -former i arbejderklassen, herunder spørgsmålet om udvikling af konkrete erfarings- eller læreprocesser i denne forbindelse, bliver på denne baggrund slet ikke berørt.

\section{Selvhjælpsorganiseringen og arbejder- klassens organisationsformer}

I takt med dannelsen af en organiseret arbejderbevægelse (især fagforeninger) udbredtes forskellige former for selvhjælpsorganisering i arbejderklassen som en reaktion mod det fremvoksende lønarbejdes trussel mod eksistensbetingelserne. Det skete meget ofte i første omgang ved en overtagelse af lavsvæsenets forskellige former for sikringssystemer.

Denne selvforsikring mod sygdom og arbejdsløshed der udgjorde de største trusler mod eksistensen som lønarbejder var oprindelig frivillig og bidrog $\mathrm{i}$ høj grad til at styrke solidariteten klassemedlemmerne imellem. MR opregner nogle træk ved denne selvorganiserings forsikringsprincipper (s. 117) som karakteristiske for en solidarisk orientering i selvhjælpsorganiseringen: frivillighed mht. deltagelse og bidrag, overskuelighed af medlemsskaren og social homogenitet. Endelig at ydelserne formidles som pengeydelser og dermed var til disposition for den enkelte forsikredes egen organisering af sin reproduktion.

Heroverfor er den statslige regulerede tvangsforsikring karakteristisk ved en række forhold, der forstærker individualiseringen og det sociale kontrolmoment i sikringssystemet - forhold der i sidste instans træder tydeligt frem ved de statslig organiserede reproduktionssikringssystemer, der direkte overtager og organiserer dele af den tidligere private reproduktion.

På denne baggrund er det MR's hensigt at fors $\varnothing$ ge at forklare »hvordan det i Tyskland er kommet dertil, at arbejdernes organiserede sikring har mistet deres solidaritetsdannende funktion og at principper der underst $\varnothing$ tter en individualisering har kunnet trænge frem« (s. 120).

Her træder konsekvensen af MR's manglende forståelse af vare- og $1 \varnothing n-$ form tydeligt frem. Problemet er nemlig ikke kun en modsætning mellem den klasseorienterede selvhjælpsorganisering og dennes muligheder for at understøtte klassebevidsthed og reproduktion af arbejderen (i det konkrete eksempel sundhedsforhold og især præventive foranstaltninger) overfor den statslige 
reproduktionsorganisering med dens formidling af social kontrol og dens reaktive behandlingskarakter. Problemet er, at begge typer reproduktionssikringer lader den af den samfundsmæssige reproduktionslogik bestemte reproduktionsform den individuelle lønarbejder evt. med familie - være uantastet. Eller rettere, reproduktionsformen tages som en given uproblematisk forudsætning i den såkaldte klasseorganiserede selvhjælp, mens det er den statslige sikring, der igennem den historiske udvikling har afprivatiseret visse reproduktionsområder og overtaget dem i en statslig organiseret form, som forstcerker hele kontrolaspektet på en kvalitativ anden måde end forsikringssystemet og dets ydelser. Men for MR's problemstilling er det uheldigt, at denne differentiering $\mathrm{i}$ analysen af reproduktionssikringen end ikke antydes, idet der også inden for selvhjælpsorganiseringens område kan differentieres mellem fors $\emptyset \mathrm{g}$ på selvhjælp, der i en kollektiv eller kooperativ form forsøger at ophæve partikulariseringen mellem de individuelle reproduktionsenheder - en ophævelse, der udtrykker en egentlig klassesolidaritet - og så de former for selvhjælp, der i en ren forsikringsform lader reproduktionsformen uantastet og blot sigter mod at sikre eksistensen som lønarbejder. Denne sidste types binding til fordelingsforholdene gennem lønformen gør, at den i takt med kapitalforholdets historiske udbredelse og dermed tendentielle forværring af eksistensbetingelserne for arbejderklassen nødvendigvis må gennemtvinge en form for statsliggørelse af løsningen på reproduktionsproblemerne for arbejderklassen. Herved etableres historisk den dobbelthed ved den borgerlige stats socialpolitiske foranstaltninger, som grunder sig i, at de oftest er fremkommet gennem arbejderklassens kamp for at sikre sin eksistens som varesælgere $o g$ samtidig hermed en for den samfundsmæssige kapital i en historisk situation nødvendig reproduktion af en specifik mængde udbyttelig arbejdskraft - som Müller/Neusüss allerede påviste det i $1970 .^{2}$

Begge momenter må imidlertid fastholdes i analysen af socialpolitikudviklingen, hvis man ikke skal forfalde til en ren politisk reformismeforklaring og opgive at forklare reformismen ud fra arbejderklassens umiddelbare eksistenskamp i fagforeningerne og dens orientering mod staten som en tilsyneladende uafhængig instans i det borgerlige samfund.

Men MR inddrager jo netop ikke en analyse af de vidt forskellige eksistensbetingelser og -muligheder for forskellige arbejdergrupper $i$ den konkrete akkumulationsudvikling, som er af central betydning for en analyse af de reproduktionssikringskrav og den politik, der fra fagforeningernes side rettes mod staten. Og hvilke af disse modsætningfyldte reproduktionssikringsstrategier, der vejer tungest og dermed kommer til at afstikke den konkrete arbejderbevægelsespolitik overfor staten, kan kun bestemmes på grundlag af en analyse af arbejderklassens differentierede materielle eksistensvilkår.

\section{Statslig kontrol gennem socialpolitik}

Efter en periode $\mathrm{i}$ midten af sidste århundrede mistede selvhjælpsorganiseringen sin centrale plads i solidaritetsog klassebevidsthedsdannelsen til fordel for fagforeningerne og senere $i$ 1860'erne under Lasalle's dominans i den tyske arbejderbevægelse til fordel for kampen for statsst $\varnothing$ ttede produktionsassociationer.

Det er foran vist at ændringer i de former som arbejderklassen søger at tilkæmpe sig en eksistens igennem, må analyseres med udgangspunkt i de 
differentierede materielle eksistensvilkår for de forskellige lag og grupper i arbejderklassen.

De mange meget differentierede forsøg på organisering af eksistenskampen i denne tidlige periode i kapitalismen får i den videre historiske udvikling mindre og mindre betydning og opsuges og indkapsles i den organisationsform der direkte udspringer af lønarbejdet og lønformen, fagforeningerne. De tidligere decentrale og autonome fagforeningskampe med det lokale samarbejde med selvhjælpskasserne indordnes nu under den landsdækkende fagbevægelse og dennes samarbejde med socialdemokratiet.

Centraliseringen af fagbevægelsen betyder, at arbejdsdelingen i $\varnothing$ konomisk og politisk kamp mellem fagbevægelse og parti mere og mere tager organisatorisk form og reproducerer den adskillese mellem økonomi og politik, der er et grundlæggende træk ved det borgerlige samfund. Udover en ind i mellem opblussende konkurrence om den politiske magt i arbejderbevægelsen mellem patiledelsen og fagbevægelsens top, er der tale om en underordning af fagbevægelsen i og med, at den politiske kamp også skal sikre rammerne for den faglige kamp: dels sikre de borgerlige rettigheder såsom organisationsfrihed, dels et af MR fremhævet forhold som selvforvaltning af hjælpekasserne.

Ifølge MR betød sociallovene og forsikringslovene fra 1876 og frem en undergravning og ophævelse af de i forhold til staten autonome funktioner mht. arbejderklassens reproduktionssikring. Alligevel var der, fremhæver R., mulighed for en ret omfattende omgåelse af den statslige kontrol ved en udnyttelse af selvforvaltningen i kasserne, den selvforvaltning, som var indført i 1883. Styrelsen var valgt i forhold til det $\varnothing \mathrm{ko}-$ nomiske grundlag for finansieringen af forsikringen, dvs. 1/3 arbejdsgivere og 2/3 forsikrede. Selvforvaltningskontrollen omfattede dels kontrol med ydelserne, dels iværksættelse af visse former for forebyggelse af almen-præventiv karakter. Udnyttelsen af denne selvforvaltning var i en periode politisk vigtig for arbejderbevægelsen. Men især hele den forebyggende, almen-præventive del var i sig selv en forkastelse af forsikringsprincipperne og udgjorde en del af forklaringen på den politiske drejning bort fra forsikringskasserne, som blev overladt til fagbevægelsens administrative bureaukrati, og over mod en direkte politisering omkring de statslige politikker, omkring reformpolitik (arbejderbeskyttelse).

MR forklarer dette med 1), at forsikringskasserne altid havde været underordnet lønkampen og arbejderbeskyttelseskampen, 2) revisionismen i SPD som især gjorde sig gældende i den centralistiske fagbevægelse, 3) SPD's organisatoriske interesser $\mathrm{i}$ at få socialdemokratiske partifunktionærer ind i statens tjeneste og 4) spredte eksempler på tæt samarbejde mellem arbejdsgivere og arbejdere i lokale kasser, især omkring fælles interesser i omkostningsreduktion for sygeforsikringen, hvilket blev betragtet som et politisk problem.

MR sammenfatter det således: »Denne udviklingstendens i forholdet mellem kassens arbejderselvforvaltning og partiet peger allerede på de indre strukturelle svagheder i disse socialistiske institutioner i den borgerlige stat. Disse svagheder havde deres årsag i arbejderpartiets manglende støtte og kom kun til syne i den langsomme afvikling af arbejderselvforvaltningsorganerne gennem den videre statslige sociallovgivning.« (154)

At kalde kasserne for »socialistiske institutioner i den borgerlige stat « er 
på flere måder totalt fejlagtigt. Som jeg allerede har været inde på, så er de socialistiske aspekter ved denne form for reproduktionssikring ude af billedet på det tidspunkt, hvor der ikke (længere) kan lokaliseres fors $\varnothing \mathrm{g}$ på at gøre op med, at den givne individuelle reproduktionsform (familien) forbliver udgangspunkt for reproduktionssikringsfors $\emptyset$ gene. $\mathrm{Og}$ årsagen til at selvhjælpsorganiseringen så hurtigt kunne indordne sig under det borgerlige samfunds reproduktionsformer var ikke så meget den manglende politiske st $\varnothing t t e$, som MR fremhæver men det forhold, at disse systemer til reproduktionssikring ikke forholdt sig til produktionsrelationerne, men udelukkende var opbygget som fordelingspolitiske foranstaltninger.

Meget hurtigt, dvs. fra begyndelsen af 1860'erne blev selvhjælpsorganiseringen indordnet under det borgerlige samfunds retsregulering og senere direkte under statslig rammekontrol og -styring. Yderligere havde den i kapitalakkumulationens nedgangsperioder forværrede situation for arbejderklassen og dennes absolutte og relative vækst i befolkningen aktualiseret krav om mere omfattende fordelingspolitiske reproduktionsforanstaltninger end kasserne kunne gennemføre.

Og løsningen blev krav om statstilskud/statsfinansiering, hvis grundlag er og var de statslige indtægter, primært skatterne, både direkte og indirekte.

Men dette oveskygger ikke at MR, som det tidligere er påvist, udgår fra en i egentlig forstand a-teoretisk tilgang til analysen af arbejderklassens reproduktionskamp og reproduktionspolitik. Fremfor at forstå reformismen i arbejderbevægelsen som den nødvendige form for lønarbejderbevidsthed der eksisterer i og af de former for organisering af reproduktionskampen, som fastholder arbejdskraftens vareform, fagforeninger og socialdemokrati, opstiller MR, som i så mange af de nyere reformismeanalyser, en abstrakt revolutionær arbejderklasse som målestok for den historiske udvikling og udgangspunkt for periodisering af historien. Og i stedet for at analysere den konkrete reformisme ud fra de givne materielle kapitalistisk satte reproduktionsbetingelser i den form de fremtræder d.v.s. på samfundets overflade, opstilles abstrakte krav om »modmagt« og »selvforvaltning « uden antydning af analyse af den nødvendige udvikling $\mathrm{i}$ den kapitalistiske reproduktion, der kunne muliggøre en tendentiel nedbrydning af de givne bevidsthedsformer.

Fraværet i MR's analyse af en undersøgelse af arbejdskraftens reproduktionsformer har som nævnt som konsekvens, at undersøgelsen af selvorganiseringen forbliver overfladisk i den forstand, at de kapitalistiske reproduktionssammenhænge overhovedet ikke behandles i analysen.

\section{Kontrol og reproduktionsform}

Arbejdskraftens vareform betyder, at differentieringer i reproduktionsomkostninger og individuelle svigt $\mathrm{i}$ reproduktionen, som ikke har baggrund $\mathrm{i}$ den specifikke form for arbejdskraft som skal reproduceres (f.eks. sygdom, overgennemsnitligt antal børn), ikke kan tilgodeses i arbejdslønnen, d.v.s. i den reproduktionssikring der fremkommer fra den umiddelbare konfrontation med kapitalen omkring salget af arbejdskraften. Forudsætningen for at sælge arbejdskraften til dens værdi har som minimum en reduktion resp. ophævelse af konkurrencen arbejderne imellem. Individuelle forskelligheder som ikke har noget med den specifikke form for arbejdskraft at gøre, kan ikke tilgodeses i arbejdsløn- 
nen. Eller sagt på en anden måde; det er ikke en forkert reformistisk politik at kræve ens løn for salg af samme slags arbejdskraft, men det er overhovedet en forudsætning for den faglige organisering og dermed for en tilkæmpet eksistens under kapitalismen (værdimæssig reproduktion). Hermed er spørgsmålet om at tilgodese de varierende individuelle reproduktionsomkostninger, som ikke kan dækkes gennem arbejdslønnen, lagt udenfor den organisatoriske form der udspringer af salget af arbejdskraft fagforeningerne - og over til forholdet mellem private borgere, til interessekampen og dermed til staten. Og dette forhold mellem den fagforeningsmæssige og den politiske (statslige) reproduktionssikring udvikler sig i faste former og med komplekse sammenkædninger i løbet af den kapitalistiske akkumulationsudvikling og udgør indholdet i et historisk begreb om reformismen. MR's abstrakte krav om 'politisering' og 'decentral selvforvaltning', fremstår som meningsløse og naive, da de ikke er begrundet $i$ en analyse af den historiske udvikling $\mathrm{i}$ forholdet mellem de forskellige former for reproduktionssikring og slet ikke af de modsætninger og brydninger heri, som kunne lokaliseres, hvis reproduktionsbetingelserne under den aktuelle kapitalistiske krise havde været inddraget. Uden en sådan materiel fundering af brudflader i reproduktionsformerne er spørgsmålet om at stille reformkrav med socialistisk sigte meningsløst.

Det blev før fremhævet, at R. aktualiserede kontroldiskussionen i forbindelse med socialpolitikanalysen, men samtidig begrænsede problemet til et snævert legalt og juridisk kontrolproblem. Årsagen hertil er allerede lokaliseret $\mathrm{i}$ den manglende reflektion ud fra den marx'ske teori om den kapitalistiske produktionsmåde som kendetegner R.'s analyse.

Kontrollen med arbejderklassen er fundamentalt grundlagt i kapitalens reproduktionssammenhænge og den diskussion der er gennemført her med udgangspunkt i de problemer MR rejser, berører kun kontrolproblemet i en afgrænset sammenhæng, nemlig omkring statens intervention i reproduktionen af arbejdskraften. Men også i denne sammenhæng er MR's tilgang utilstrækkelig, idet den ikke lægger op til en systematisk diskussion af statsiterventionen i reproduktionen af arbejdskraft.

Med den stigende statsliggørelse af dele af arbejdskraftens reproduktion vokser så ikke blot beskatningen tilsvarende og dermed den statslige kontroludøvelse i økonomisk forstand og som rammekontrol overfor arbejderklassen. Helt uden for MR's diskussion, men af betydelig større vigtighed, er problemet, at den tidligere rammekontrol med den private reproduktions omfordelingssikringer erstattes med en kvalitativ anden og mere direkte kontrol, der er snævert forbundet med selve statsliggørelsen af dele af arbejdskraftreproduktionen. Denne form for kontrol baserer sig på den direkte statslige udformning og styring af indholdet $\mathrm{i}$ disse overtagne reproduktionsområder.

Tidligere blev der rejst et spørgsmål om betingelserne for den gnidningsl $\varnothing$ sestatsliggørelse af selvhjælpsorganiseringen.

Svaret på dette spørgsmål ligger ikke i en mangel på en tilstrækkelig revolutionær politik fra arbejderklassens side, som MR antyder, men i, at selvhjælpsorganiseringen tager udgangspunkt i arbejdskraftreproduktionens vareform og heroverfor søger at modificere forskelle i reproduktionsomfang mellem de forskellige lønarbejdere via en om- 
fordeling der organiseres i forsikringsform. I det umiddelbare forhold mellem arbejdskraft og kapital er salget af arbejdskraft betinget af reproduktion af en for kapitalen brugbar arbejdskraft (brugsværdi), som formidles $\mathrm{i}$ vareform. Dvs. reproduktionen påtvinges vareform, hvilket som allerede påvist indebærer en udelukkelse af differentierede og individuelle reproduktionsvariationer i arbejdslønnen, dvs. i lønformen. Men lønformen formidler samtidig en adskillelse mellem kapitalens reproduktionskredsløb og arbejdskraftens private reproduktion. Denne adskillelse er dog samtidig arbejdskraftreproduktionens ubetingede afhængighed af kapitalakkumulationen formidlet over salget af arbejdskraften, hvilket forudsætter at denne stadig reproduceres og udgør grundlaget for eksistensen. Den formmæssige adskillelse skaber dog muligheden for omfordelinger mellem de enkelte lønarbejdere med sigte på at modificere forskelle i reproduktionsbetingelserne $\mathrm{i}$ forhold til den umiddelbart udbetalte arbejdsløn.

En sådan omfordeling er imidlertid fuldt forenelig med de kapitalistiske reproduktionsformer. Den antaster ikke disse, men kan netop medvirke til at sikre det samlede reproduktionssystem, dvs. den samfundsmæssige totalkapitals reproduktion, herunder reproduktionen af den for kapitalen nødvendige mængde arbejdskraft. Selvhjælpsorganiseringens udformning som en omfordeling mellem lønarbejderne gennem forsikringsformen har således den vareformbestemte arbejdskraftreproduktion som sit grundlag og kan derfor umiddelbart indgå i den borgerlige stats arbejdskraftreproduktive (socialpolitiske) foranstaltninger. Dette kan ske direkte gennem hel eller delvis statslig overtagelse af omfordelingsydelserne og finansieringen eller indirekte gennem statslig regulering og kontrol.

Hvornår dette historisk sker, er afhængig af omfanget af reproduktionsproblemerne i arbejderklassen og dennes politiske styrke til at gennemtvinge forbedringer $\mathrm{i}$ sine eksistensbetingelser via statsindgreb, d.v.s. som kæmpende reformistisk arbejderbevægelse. At det nødvendigvis må ske som statsindgreb i form af en socialpolitisk fordelingspolitik ligger begrundet $\mathrm{i}$ den form for reproduktionssikring, som den forsikringsopbyggede selvhjælpsorganisering tager udgangspunkt i, nemlig sikring af den vareformbestemte reproduktion. Den reformisme i arbejderklassen hvori bl.a. de statslige socialpolitikker indgår, er ikke en politisk degenerering af arbejderklassen fra et oprindeligt revolutionært standpunkt som R. angiver, men udtryk for den form som eksistenskampen konkret antager, betinget af den samlede klassestruktur, differentieringer i arbejderklassen og i $\varnothing$ vrigt de former, som kapitalakkumulationens angreb på reproduktionen tager.

\section{NOTER}

1. Rodensteins artikel findes $\mathrm{i}$ antologien Starnberger Studien 2, Sozialpolitik als soziale kontrolle, Frankfurt 1978. De øvrige artikler i antologien diskuterer kontrolproblemstillingen i en bredere og mere almen ramme end Rodenstein.

2. W. Müller og C. Neusüss, Die Sozialstaatsillusion und die Widerspruch von Lohnarbeit und Kapital, $i$ Prokla, sonderheft 1, 1970. Dansk udgave $i$ Mattick, Müller og Neusüss, Socialstat og blandingsøkonomi, DSF 1974. 


\section{RØDE HANE}

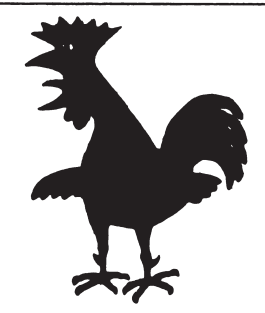

Preben Wilhjelm:

DET REPRAESENTATIVE DEMOKRATII PRAKSIS 32 sider,

ab.-pris 5 kr. 10 stk. for $35 \mathrm{kr}$.

Preben Wilhjelm:

"FOLKESTYRET “

I PRAKSIS - 2

32 sider,

ab.-pris $5 \mathrm{kr}$. $10 \mathrm{stk}$. for $35 \mathrm{kr}$.

Folketinget:

\section{LANGSIGTEDE MÅL}

56 sider, ab.-pris $10 \mathrm{kr}$.

\section{LIP-LIP-HURAA!}

160 sider ill. ab.-pris $12 \mathrm{kr}$.

Paul Mattick:

\section{MARX OG KEYNES}

304 sider, ab.-pris $20 \mathrm{kr}$.

Jørgen Stender Clausen (red.):

IL MANIFESTO KLASSE,

PARTI, ARBEJDERRÅD

272 sider, ab.-pris $18 \mathrm{kr}$.

\section{Egon Clausen:}

DANSK BØRNELAERDOM

112 sider ill., ab.-pris $12 \mathrm{kr}$.

Forfatterkollektiv:

FILMANALYSER -

HISTORIEN I FILMEN

368 sider, ab.-pris $29 \mathrm{kr}$.

Vilhelm Borg:

INDUSTRIARBEJDE/

ARBEJDERBEVIDSTHED

Med diskussionsbidrag af

Kjeld Schmidt, Niels Mortensen

og Erik Christensen,

232 sider, ab.-pris $18 \mathrm{kr}$.

KORREKTIV TIL

GYLDENDALS HF-GEOGRAFI

90 sider ill., ab.-pris $6 \mathrm{kr}$.

Isi Grünbaum:

KAPITALISMENS

POLITISKE ØKONOMI

176 sider, ab.-pris $20 \mathrm{kr}$.

Anne Grunnet:

MASSEKOMMUNIKATION

I KINA

149 sider ill., ab.-pris $14 \mathrm{kr}$.

GRABBERNE VAEK FRA BYGGEREN

32 sider, illustreret, stort format, ab.-pris $15 \mathrm{kr}$.

Man abonnerer ved at indsende beløbet til Forlaget Røde Hane, Amalievej 14, $1875 \mathrm{Kbh}$. V., på postgiro 5551544.

Bøgerne bliver tilsendt portofrit. 